\title{
Allozyme inheritance, heterozygosity and outcrossing rate among Pinus monticola near Ladysmith, British Columbia
}

\author{
Y. A. El-Kassaby*† \\ M. D. Meagher \\ J. Parkinson§ and \\ F. T. Portlock $\ddagger$
}

\author{
* CIP Inc., Tahsis-Pacific Region, Saanich Forestry \\ Centre, 8067 East Saanich Road, R.R. 1, Saanichton, \\ B.C., Canada VOS $1 \mathrm{MO}$ \\ $\dagger$ Faculty of Forestry, University of British Columbia, \\ Vancouver, B.C. V6T 1W5. \\ $\ddagger$ Canadian Forestry Service, 506 West Burnside \\ Road, Victoria, B.C. V8Z 1 M5. \\ $\S$ British Columbia Ministry of Forests, Coastal Seed \\ Orchards, Box. 816, Duncan, B.C. V9L 3 Y2.
}

Analysis of megagametophytic and embryonic allozyme variants in nine enzymatic systems encoded by 14 loci was conducted on 30 western white pine (Pinus monticola Dougl.) trees from a natural stand on Vancouver Island, B.C. The segregation of allozymes in megagametophytes of heterozygous trees indicated distinct, simple, Mendelian inheritance. The stand heterozygosity parameters (proportion of polymorphic loci $(0 \cdot 64)$, average number of alleles per locus (1.79), and average expected heterozygosity $(0 \cdot 18)$ ) were identical to those reported from a broadly-based survey of the species (Steinhoff et al., 1983). Comparison of progeny (viable embryo) and parental genotypic distributions indicated a major genetic shift between the two life-cycles phases. Among the progeny, heterozygotes occurred less frequently than expected under panmixia, while the reverse was observed for the parental population. Single-locus estimates of outcrossing rate varied between 0.751 and 1.043 and were significantly heterogeneous. Comparison between the single-locus estimates and the multilocus estimate $(0.977)$ of outcrossing rates indicated that most of the inbreeding detected was due to consanguineous matings, rather than selfing. This form of inbreeding was consistent with the clustering of genotypes in the stand. Single-tree estimates of outcrossing rate varied considerably among trees and ranged between 0.682 and 1.207 , indicating that some trees might possess high self compatibility and tolerate high selfing, or that violation of mixed-mating assumptions occurred. The implications of the apparent inbreeding on the derivation of genetic estimates from open-pollinated seeds and on seed crops for production plantations are discussed.

\section{INTRODUCTION}

Western white pine (Pinus monticola Dougl.) is a widespread species of mesic forests in both coastal and montane areas of western North America. Its large size, good stem form and high-quality wood have made it a desirable species since commercial forest exploitation began in its range. The accidental introduction of the white pine blister rust (Cronartium ribicola J. C. Fisch.: Rabenh.) threatened white pine's status as a species for commercial management, but breeding and selecting for resistance to the rust, particularly in the U. S. "Inland Empire" (Bingham, 1983) have restored it to active planting status in Oregon, Washington, Idaho and Montana (Hoff, 1982; Samman, 1982). This progress, plus the high resistance of western white pine to root diseases affecting some of its important associates (Wallis, 1976) has led to the resurrection of a tree-improvement program for the species in British Columbia (B.C.), Canada (Meagher and Hunt, 1985).

Following experience in the U.S. programs, screening of open-pollinated (OP) families from canker-free parents is proposed for B.C. as a quick and inexpensive method of identifying parents possessing useful amounts of resistance. To obtain reliable values of genetic parameters from such trials, the parents should be unrelated, should be good outcrossers and should have produced progeny equally derived from many pollen parents (Namkoong, 1966). However, relatedness and natural inbreeding have been reported for several conifers (El-Kassaby et al., 1981; Park and Fowler, 
1982; Shaw and Allard, 1982a; Roberds and Conkle, 1984), including temporal variation in the same stand (King et al., 1984; Cheliak et al., 1985). Hence, quantitative assessment of the outcrossing rates should be an integral part of any study of selection in plant populations (Ennos, 1981).

The objectives of this study were to determine the inheritance of enzyme markers, estimate the degree of heterozygosity, and characterise the mating system in a young white pine stand in coastal B.C. Such data are useful in designing seed orchards and in estimating the bias caused by relatedness in OP seed crops.

\section{MATERIAL AND METHODS}

\section{Population description}

The stand sampled occupies ca. $50 \mathrm{ha}$; it occurs at $800 \mathrm{~m}$ elevation on a $\mathrm{N}$ to $\mathrm{NE}$ aspect west of McKay Lake near Ladysmith, British Columbia (source lat. $49^{\circ} 01^{\prime} \mathrm{N}$, long. $124^{\circ} 04^{\prime} \mathrm{W}$ ). This stand originated via natural seeding following logging, which began in the late 1940 s. Maximum tree age was approximately 34 years in 1984, although some white pines were 10 years younger. Associated species are Douglas-fir, (Pseudotsuga menziesii (Mirb.) Franco), western hemlock (Tsuga heterophylla (Raf.) Sarg.), western red cedar (Thuja plicata Donn), yellow cypress (Chamaecyparis nootkatensis (D. Don) Spach), amabilis fir (Abies amabilis (Dougl.) Forb.), red alder (Alnus rubra Bong.) and willows (Salix spp.).

The stand is reasonably open grown, with live branches at or near the ground where artificial pruning has not been conducted. White pine blister rust is present and has infected most trees, killing many.

\section{Cone and seed material}

Cones were collected from the upper $\frac{1}{3}$ of the crown in 1984 during a general, but moderate, cone crop. Thirty trees, many near a road through the stand, were selected simply on the criterion of bearing sufficient cones for collection; presence or absence of blister rust was noted for each tree. The location of each tree sampled appears in fig. 1.

Parental identity was maintained from cone collection through to seed storage. Seeds were dewinged by hand prior to cleaning in a closelyregulated air column (Edwards, 1979). All seeds were screened by soft X-ray to determine the percentage of filled and empty seeds per parent prior to winnowing. Filled deeds were stored under refrigeration $\left(2^{\circ} \mathrm{C}\right)$ until needed.

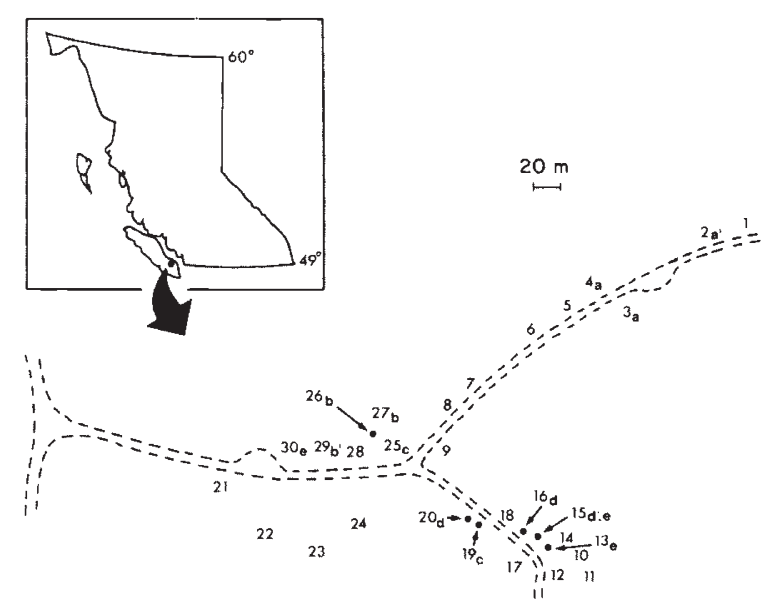

Figure 1 Location of sampled area and position of trees within the stand. $1,2, \ldots, 30$ indicate position of cone parents; "a, a" denote "identical" (6-locus) genotypes; " $a$ ", denotes "full-sib" tree differing from "identical" pair a, a by one band.

\section{Electrophoretic procedures}

Electrophoretic procedures, staining recipes and enzyme nomenclature used follow those of ElKassaby et al. (1982). The nine enzyme systems studied were: aspartate amino-transferase (AAT) E.C.2.6.1.1; glutamate dehydrogenase (GDH) E.C.1.4.1.2; glucose-6-phosphate dehydrogenase (G6PD) E.C.1.1.1.49; isocitric dehydrogenase (IDH) E.C.1.1.1.42; malic dehydrogenase (MDH) E.C.1.1.1.37; phosphoglucose isomerase (PGI) E.C.5.3.1.9; phosphoglucomutase (PGM) E.C.2.7.5.1; 6-phosphogluconic dehydrogenase (6PGD) E.C.1.1.1.44; and superoxide dismutase (SOD) E.C.1.15.1.1. Interpretation of electroporetic banding patterns followed the method outlined in El-Kassaby et al. (1982). Enzyme loci were identified by abbreviation and a number. The mostanodally-migrating locus was designated as 1 . Within each locus, the most-frequent band was assigned the number 1; faster and slower bands were given even and odd numbers, respectively (fig. 2).

\section{Genetic analyses}

The genotype of each tree was inferred for 14 allozyme loci by interpretation of electrophoretic assay of the haploid megagametophyte of 34 to 50 seeds per tree. The probability of misclassifying a heterozygote at a particular locus is $0 \cdot 5^{k-1}$ for $k$ megagametophytes assayed per tree (Tigerstedt, 1973). With this large number of seeds per tree, the probability of misclassifying a heterozygote is 


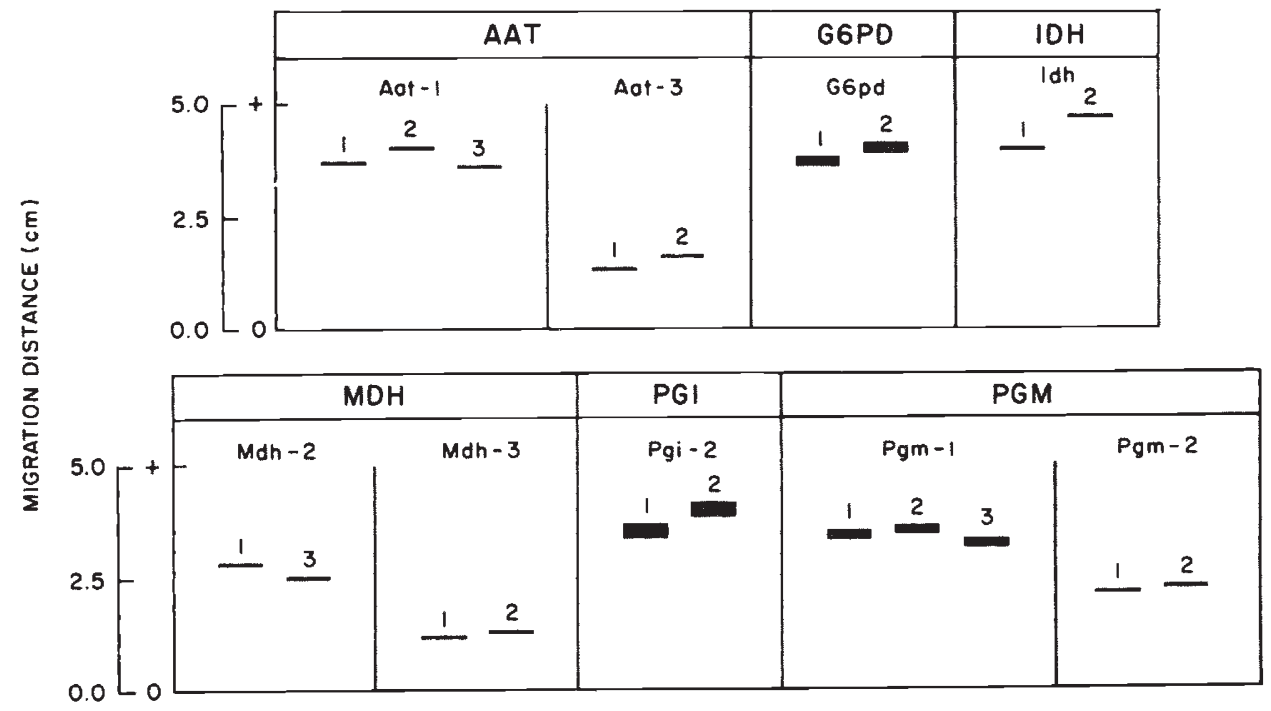

Figure 2 Banding patterns and their allelic designations for nine polymorphic loci observed in megagametophytic tissue from a natural stand of western white pine located on Vancouver Island, B.C. Number above band refers to the variant at that allozyme locus.

very close to zero. The structure of coniferous seeds (haploid megagametophyte and diploid embryo) allows detection of bands from pollen parents in the embryos.

The relationship between observed $(H)$ and expected $(h)\left(h=1-\sum p_{1}^{2}\right.$, where $p_{i}$ is the frequency of the $i$ th allele at the locus) frequencies of heterozygotes in both the parental generation and their progeny (viable-embryo stage) was used to measure the extent of inbreeding. Wright's (1922) fixation index $(F)$ was calculated using the formula $F=1-(H / h)$.

Single- and multilocus estimates of the population outcrossing rate $(t)$ and pollen allele frequencies ( $p)$ at six loci (Aat-3, G6pd, Mdh-3, Pgi-2, $P g m-1$, and $P g m-2)$ were calculated using the maximum-likelihood procedure of Ritland and ElKassaby (1985). This procedure gave estimates also of outcrossing rate and outcrossing-pollen allelic frequencies for individual trees.

Segregation analysis $(1: 1)$ was conducted after the use of the $\chi^{2}$ contingency test (Steel and Torrie, 1980) on pooled data from trees sharing the same locus genotype in their gametophytic tissue.

\section{RESULTS AND DISCUSSION}

\section{Enzyme description and inheritance}

Monomorphic enzymes Three enzyme systems (Glutamate dehydrogenase (GDH), 6-phosphogluconic dehydrogenase (6PGD), and superoxide dismutase (SOD)) were monomorphic in the 30 trees studied. GDH was found to be monomorphic, but G6PD contained a second, rare, allele in Vancouver Island populations studied by Steinhoff $e t$ al. (1983). SOD was not studied by them.

Polymorphic enzymes Six enzyme systems were found to be polymorphic for at least one locus (table 1 and fig. 2).

Aspartate amino-transferase (AAT) There were four zones of activity on AAT gels: Aat-1, Aat-2, and Aat-3, which migrated anodally, and a cathodal zone that matched variation in Aat-3. The presence of this cathodal zone was reported in other pines ( $P$. rigida, Guries and Ledig, 1978; $P$. ponderosa, O'Malley et al., 1979; P. taeda, Adams and Joly, 1980; P. strobus, Eckert et al. 1981).

Aat 1 showed three bands; the slowest one was found in only one parent (\#11) while the fastest one was found only twice in embryos (i.e., from the pollen pool). Aat-2 was monomorphic in our sample. Steinhoff et al. (1983) found one allele for this locus in Vancouver Island western white pine populations, but found two alleles elsewhere. Aat 3 showed two bands in our samples. Two bands were reported for 25 of 28 populations of western white pine (Steinhoff et al. 1983).

Gluclose-6-phosphate dehydrogenase (G6PD) A single zone of activity, containing three bands, was found. One of the "fast-migrating" bands was present in only one parent (\#5). It was difficult to 
Table 1 Observed allozyme segregation in megagametophytic tissue of heterozygous mother trees of $P$. monticola at McKay (Ladysmith) B.C.

\begin{tabular}{llcll}
\hline Locus & $\begin{array}{l}\text { Allelic } \\
\text { combination* }\end{array}$ & $\begin{array}{l}\text { Observed } \\
\text { segregation }\end{array}$ & $\begin{array}{l}\text { Deviation } \\
\chi^{2}(1 \mathrm{df})\end{array}$ & $\begin{array}{l}\text { Heterogeneity } \dagger \\
G(\mathrm{df})\end{array}$ \\
\hline Aat -1 & $1 / 3$ & $17: 23$ & $0 \cdot 90$ & - \\
Aat -3 & $1 / 2$ & $285: 324$ & $2 \cdot 50$ & $7 \cdot 81(15)$ \\
G6pd & $1 / 2$ & $192: 192$ & $0 \cdot 00$ & $2 \cdot 49(9)$ \\
Idh & $1 / 2$ & $18: 22$ & $0 \cdot 40$ & - \\
Mdh -2 & $1 / 3$ & $39: 41$ & $0 \cdot 05$ & $1 \cdot 25(1)$ \\
Mdh-3 & $1 / 2$ & $238: 248$ & $0 \cdot 21$ & $2 \cdot 70(11)$ \\
Pgi-2 & $1 / 2$ & $402: 363$ & $1 \cdot 99$ & $5 \cdot 64(18)$ \\
Pgm-1 & $1 / 2$ & $199: 203$ & $0 \cdot 04$ & $6 \cdot 52(9)$ \\
Pgm-2 & $2 / 3$ & $20: 20$ & $0 \cdot 00$ & - \\
\hline
\end{tabular}

* Allozymes were numbered starting with "1" for the most common allele; faster and slower alleles were given even and odd numbers, respectively.

$\dagger$ None of the heterogeneity $\chi^{2}$ and G-tests was significant.

differentiate this band from the most-common one, particularly in embryos, therefore, data for both bands were combined. The second "fast" band was found in 10 trees. This locus was not studied by Steinhoff et al. (1983).

Isocitrate dehydrogenase (IDH) A single zone of activity was present with two bands; the faster one was found in gametophytes of parent 19. Steinhoff et al. (1983) reported that the Idh locus was monomorphic in western white pine from Vancouver Island but that a second allele was present in Interior Washington and southern populations.

Malate dehydrogenase (MDH) Three zones of activity were detected on gels stained for $\mathrm{MDH}$. $M d h-1$ could be stained, but it was smeary and inconsistent; it was not included in further analyses. $M d h-2$ and $M d h-3$ displayed two bands. The slower band for $M d h-2$ was found in only two parents (\#25 and 29).

One MDH locus was reported for western white pine by Steinhoff et al. (1983). Among other pines, the resolution of $\mathrm{MDH}$ band patterns varies and the number of loci reported differs (see El-Kassaby, 1981, for review).

Phosphoglucose isomerase (PGI) PGI gels showed two zones of activity: Pgi-1 was monomorphic and Pgi-2 was dimorphic in our population and in all 28 western white pine populations studied by Steinhoff et al. (1983).

Phosphoglucomutase (PGM) Two zones of activity were observed for PGM. Three and two bands were observed for Pgm-1 and Pgm-2, respectively. Heterozygous embryos displayed twobanded monomeric patterns. Four bands were observed for Pgm-1 in several western white pine populations (Steinhoff et al., 1983).

In summary, no significant deviation from the expected 1:1 segregation ratio nor Gheterogeneity test was observed at any locus studied, indicating that these allozymes exhibited distinct, co-dominant expression and simple Mendelian segregation in their mode of inheritance. With the exception of Pgm-1 and Pgm-2, all loci showed triple-banded heterozygotes indicating dimeric subunit structures.

\section{Population heterozygosity level}

Individual-tree heterozygosity ranged from 0.00 to 0.36 , with a mean expected heterozygosity of 0.18 (Table 2). When the McKay population heterozygosity parameters (i.e., proportion of polymorphic loci, average number of alleles per locus, and average expected heterozygosity) were compared with those from the more extensive samples of Steinhoff et al. (1983) and, more specifically, with their Vancouver Island populations ("Coronation" and "Victoria"), the values correspond closely, in spite of differences between the two studies in the loci examined and their number (Table 2).

In summary, considerable variation in the amount of genetic polymorphism among the studied loci was observed in this population. These observations are consistent with the results of Steinhoff et al. (1983) and are typical of those for most coniferous trees studied by isoenzyme techniques (Mitton, 1983). Nine of the 30 trees sampled were free of blister rust. Mean heterozygosities per tree for cankered-uncankered classes were 0.206 and $0 \cdot 183$, respectively. The difference is not 
Table 2 Summary of heterozygosity parameters in Pinus monticola at McKay, B.C. and comparisons to reported parameters

\begin{tabular}{llll}
\hline Parameter & McKay* & $\begin{array}{l}\text { Vancouver } \\
\text { Island }\end{array}$ & Rangewide $\dagger$ \\
\hline Proportion of polymorphic loci & 0.64 & 0.67 & 0.65 \\
Average number of alleles per locus & 1.79 & 1.70 & $1 \cdot 70$ \\
Average expected heterozygosity & 0.18 & $0 \cdot 17$ & $0 \cdot 18$ \\
\hline
\end{tabular}

* Based on 14 loci.

† Based on 12 loci (Steinhoff et al., 1983).

statistically significant; thus, the presence or absence of rust cankers is not correlated with intrapopulation variability determined by this technique.

\section{Adult-progeny allelic and genotypic frequencies}

Estimates of allelic frequencies and their 95 per cent confidence intervals for ovule (maternal trees) and outcrossing-pollen gene pools for six polymorphic loci (Aat-3, G6pd, Mdh-3, Pgi-2, Pgm-1, and $P g m-2)$ are listed in table 3. Differences between any pairs of allelic frequencies were checked for significance $(P<0.05)$ by comparing bounds of confidence intervals (table 3 ). Ovule and pollen pool allelic frequencies did not differ at the 95 per cent level, indicating that the maternal trees are representative of the local population.

Estimates of Wright's inbreeding coefficient $\hat{F}$, (Wright, 1922), which measures the excess of homozygosity above Hardy-Weinberg expectations, varied widely among loci for both adult

Table 3 Allelic frequencies and their 95 per cent confidence intervals for six polymorphic loci in the maternal, and outcrossing pollen pools of Pinus monticola at McKay, B.C.

\begin{tabular}{|c|c|c|c|}
\hline Locus & Allele* & Maternal & Outcrossing pollen \\
\hline \multirow[t]{2}{*}{ Aat -3} & 1 & $0.733 \pm 0.112$ & $0.769 \pm 0.025$ \\
\hline & 2 & $0 \cdot 267 \pm 0.112$ & $0.231 \pm 0.025$ \\
\hline \multirow[t]{2}{*}{ G6pd } & 1 & $0.833 \pm 0.094$ & $0.807 \pm 0.023$ \\
\hline & $2 \dagger$ & $0.167 \pm 0.094$ & $0.193 \pm 0.023$ \\
\hline \multirow{2}{*}{$M d h-3$} & 1 & $0.500 \pm 0.127$ & $0.490 \pm 0.029$ \\
\hline & 2 & $0.500 \pm 0.127$ & $0.510 \pm 0.029$ \\
\hline \multirow[t]{2}{*}{ Pgi-2 } & 1 & $0.650 \pm 0.121$ & $0.679 \pm 0.027$ \\
\hline & 2 & $0.350 \pm 0.121$ & $0.321 \pm 0.027$ \\
\hline \multirow[t]{2}{*}{$P g m-1$} & 1 & $0.783 \pm 0.104$ & $0.843 \pm 0.021$ \\
\hline & $2 \dagger$ & $0 \cdot 217 \pm 0.104$ & $0.157 \pm 0.021$ \\
\hline \multirow[t]{2}{*}{$P g m-2$} & 1 & $0.783 \pm 0.104$ & $0.689 \pm 0.027$ \\
\hline & 2 & $0.217 \pm 0.104$ & $0.311 \pm 0.027$ \\
\hline
\end{tabular}

* See table 1 for allelic designation.

† Synthetic allele (all alleles but the most common were bulked in one class). (maternal) trees and progeny (table 4). In maternal trees, single-locus fixation indices were negative for four of six loci, while only two were negative in the progeny (table 4). The minimum-variance mean of $\hat{F}$ over loci for the maternal trees $(\hat{\bar{F}}=$ $-0 \cdot 105)$ differed significantly from $\hat{F}=0$, indicating an excess of heterozygotes over those expected from panmixia (table 4). In contrast, the mean of $\hat{F}$ over progeny loci was positive (table 4 ), indicating that inbreeding has taken place in the seed crop. Similar observed variation in $\hat{F}$ among loci in hoth embryo samples and parent trees has been observed for Douglas-fir (Shaw and Allard, 1982b).

Positive deviation from zero (excess of homozygotes) can result from a variety of causes: a Wahlund effect (Wahlund, 1928), positive assortative mating (i.e., preferential mating among similar genotypes) (Crow and Felsenstein, 1968), selection for homozygotes and family structure within restricted neighborhoods, causing mating among relatives (Levin and Kerster, 1971; 1974). Conversely, negative $F$ values (i.e., deficiency of homozygotes), can result from negative assortative mating (i.e., preferential mating among dissimilar genotypes) and selection favouring heterozygotes (Brown, 1979).

Table 4 Fixation indices $(\hat{F})$ and their 95 per cent confidence intervals for 30 Pinus monticola parents and their progeny at McKay, B.C.*

\begin{tabular}{|c|c|c|}
\hline Locus & Maternal & Progeny $\dagger$ \\
\hline Aat -3 & $-0.363 \pm 0.076$ & $-0.003 \pm 0.002$ \\
\hline G6pd & $-0.198 \pm 0.047$ & $-0.024 \pm 0.002$ \\
\hline$M d h-3$ & $0 \cdot 200 \pm 0 \cdot 165$ & $0.028 \pm 0.002$ \\
\hline$P g i-2$ & $-0.391 \pm 0.086$ & $-0.007 \pm 0.002$ \\
\hline Pgm-1 & $-0.079 \pm 0.066$ & $0.061 \pm 0.002$ \\
\hline Pgm-2 & $0.315 \pm 0.061$ & $0.003 \pm 0.002$ \\
\hline$\hat{\hat{F}}$ & $-0.105 \pm 0.028$ & $0.011 \pm 0.001$ \\
\hline
\end{tabular}


Natural selection tends to reduce the frequency of homozygotes in natural stands (Stern and Roche, 1974; Brown, 1979; Shaw and Allard, $1982 \mathrm{~b}$ ). Comparison of parental and progeny genotypic distributions indicates that considerable genetic shift occurred between the two life-cycle phases. If a similar bias toward inbreeding existed in the seed crop producing the cone parents sampled here, much of the reduction in homozygosity between the two phases could be due to elimination of inbreds by competition (Brown's (1979) "heterosis for outcrosses"), to differences in inbreeding among maternal trees (see matingsystem estimation section), and the presence of a Wahlund effect (Wahlund, 1928). Similar observations have been reported in both natural and experimental plant populations (Clegg and Allard, 1973; Clegg et al., 1978; Shaw and Allard, 1982b; Neale, 1985).

When populations are at inbreeding equilibrium in the absence of selection, the fixation index $(\hat{F})$ defines the outcrossing frequency $(\hat{\mathrm{t}})$ by the relationship $\hat{\mathrm{t}}=(1-\hat{F}) /(1+\hat{F})$ (Nei and Syakudo, 1958). Substituting the minimum-variance mean $(\stackrel{\vec{F}}{)}$ of 0.011 (table 4$)$ into the equation yields an expected outcrossing rate of 0.978 , which is nearly the observed value for $\hat{t}_{m}(0.977)$ (table 5). A similar situation was reported for Douglas-fir (Shaw and Allard, 1982b).

\section{Mating-system estimation}

Single-locus $(\hat{\mathrm{t}})$ and multilocus $\left(\hat{\mathrm{t}}_{\mathrm{m}}\right)$ estimates of outcrossing rates are presented in table 5 . Single-

Table 5 Single-locus $(\hat{t})$ and multilocus $\left(\hat{t}_{m}\right)$ estimates with 95 per cent confidence intervals of outcrossing among Pinus monticola at McKay, B.C.

\begin{tabular}{lll}
\hline Locus & Number of seed analysed & \multicolumn{1}{l}{$\dagger$} \\
\hline Aat -3 & 1113 & $1.027(0.083)$ \\
G6pd & 1171 & $1.043(0.079)$ \\
Mdh-3 & 1171 & $0.977(0.081)$ \\
$P g i-2$ & 1180 & $0.945(0.080)$ \\
$P g m-1$ & 1175 & $0.751(0.084)$ \\
$P g m-2$ & 1126 & $0.951(0.083)$ \\
$\bar{t} \neq$ & & $0.952(0.056)$ \\
$\hat{t}_{m}$ & 1180 & $0.977(0.023)$ \\
\hline
\end{tabular}

* Rejection of the null hypothesis that $\hat{t}=1.00$ at 5 per cent level $\dagger$ The figure in parentheses gives the 95 per cent confidence interval

\# Single-locus minimum variance mean over loci

$(\bar{t})=\left[\sum_{i=1}^{n} \frac{1}{V_{\hat{t}_{i}}}\right]^{-1}\left[\sum_{i=1}^{n} \frac{\hat{t}_{i}}{V_{\hat{t}_{i}}}\right]$ where $n=$ number of loci,

$\hat{t}_{i}=$ single-locus estimate; $V_{\hat{t}_{i}}=$ variance of $\hat{t}_{i}$ locus estimates showed significant departure from complete outcrossing $(t=1 \cdot 0)$ only at the Pgm-1 locus. Differences among single-locus outcrossing estimates have been reported for several coniferous species (Moran et al., 1980; El-Kassaby et al., 1981; Mitton et al., 1981; Shaw and Allard 1982a; Epperson and Allard 1984; King et al., 1984; Ritland and El-Kassaby, 1985). This observed variation is an inherent problem of all single-locus estimates due to their sensitivity to any violation of the assumptions of the mixed-mating model (Fyfe and Bailey, 1951; Brown and Allard, 1970; Ennos and Clegg, 1982; Brown et al., 1984).

Single-locus estimates of $\hat{t}$ are biased downward by any form of inbreeding in addition to selfing. An estimate of such possible inbreeding can be inferred by comparing values from the multilocus estimate with those from a single locus (Shaw et al., 1981; Ritland and Jain, 1981). The multilocus estimate of outcrossing rate for this population $(0.977)$ is greater than the minimumvariance, mean single-locus estimate over all loci of 0.952 (table 5), indicating that some of the inbreeding detected is due to consanguineous matings. Matings between related individuals are expected in natural stands because of the general presence of family structures and the finite limits to pollen dispersal (Stern and Roche, 1974).

The clustering of similar genotypes in the stand indicates the presence of family structure among the cone parents (fig. 1). Among the 30 parents studied, five pairs were genotypically identical for the six loci used. In two cases (trees \#3-4 and \# 26-27), the pairs occurred within approximately $20 \mathrm{~m}$ of each other, in one case (\#16-20) the trees were separated by $50 \mathrm{~m}$ and in the remaining two cases (\#13-30 and \#19-25) the trees were 90 and $210 \mathrm{~m}$ apart. In four cases, nearby trees in the stand differed by only one band from these pairs of trees, suggesting that they were siblings, while the paired trees might be selfs (fig. 1). Distances between the pairs and putative siblings varied from $20 \mathrm{~m}$ to approximately $340 \mathrm{~m}$ (the maximum separation between sampled trees is approximately $420 \mathrm{~m}$ ). Similar clusters of genotypes have been reported by Linhart et al. (1981) and Mitton et al. (1981) for a Pinus ponderosa stand.

Single-tree estimates of $t$ averaged over all loci varied among trees and ranged between 0.683 and 1.207 (fig. 3). The "biologically unrealistic" estimates of $t$ (i.e., $>1 \cdot 0)$ which were obtained could be due to negative assortative mating caused by phenological differences within and among trees (Sarvas, 1962; El-Kassaby et al., 1984), to patchy allelic distribution due to pollination (Levin and 


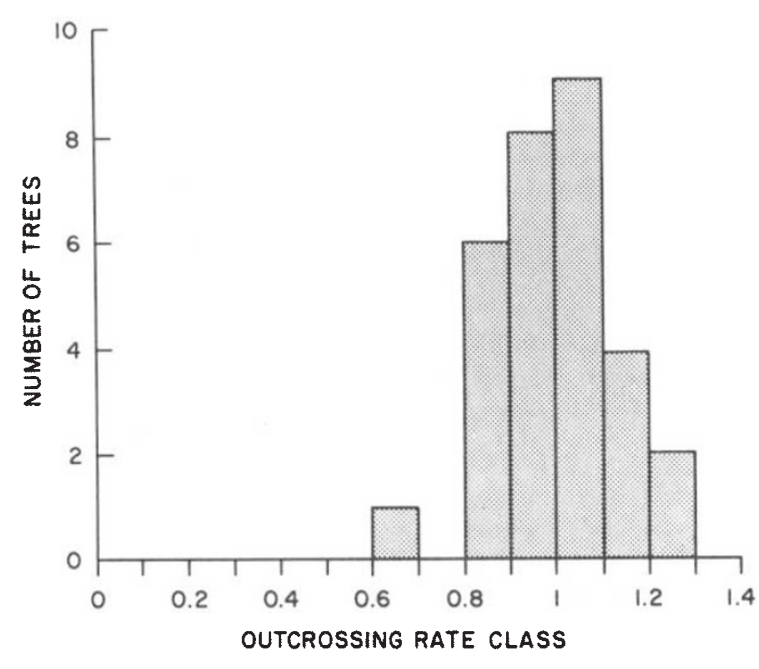

Figure 3 Frequency distribution of outcrossing rate class for 30 white pine trees sampled.

Kerster, 1968; Bradshaw, 1972; Schaal, 1974; Clegg, 1980; Hamrick, 1982), or just to sampling error. Conversely, there may be variation among single trees in their outcrossing rate as a result of genetic differences among individuals in their selfing ability.

Bingham and Squillace (1955), considered western white pine to possess self compatibility, but to differ in self fertility. However, our data indicated a non-significant correlation between percent of filled seed per tree and that tree's outcrossing rate estimate $(r=0.012, p>0.05, n=30)$. Two comparisons are worthy of comment: tree 12 gave the lowest filled-seed percentage $(27 \cdot 3$ per cent) but displayed average outcrossing rate (1.02), while the tree with the highest filled-seed level (\#29) (94.2 per cent) also showed average outcrossing rate $(0 \cdot 96)$. Furthermore, the tree (\#21) showing the lowest outcrossing rate $(0.68)$ gave near-average full seed $(71 \cdot 5$ per cent). Tree 12 may be a poor selfer, while tree 21 could be a good selfer. Bingham and Squillace (1955) found that filled-seed yield percentage from selfing vs. outcrossing varied from near-equality to near-zero. Bingham (1973) reported an influence of inbreeding level to $0.5\left(S_{1}\right.$ backcross or full-sib mating among selfs) vs. outcrossing on filled-seed percentage (26 per cent vs. 60 per cent). A different tendency is found here where outcrossing rate is only estimated.

The outcrossing rates of several plant species have revealed marked differences under different environmental conditions (for reviews see Clegg, 1980 and Mitton et al., 1981). Therefore, the out- crossing rate estimate obtained for one population may not be applicable to other populations of that species. Highly-outcrossed species are expected to house high levels of heterozygosity and demonstrate little among-population differentiation. If the level of inbreeding found here among cone parents is common among western white pine populations, it could account for the low amongpopulation differences reported for this species (Townsend et al., 1972; Steinhoff et al., 1983; Rehfeldt et al., 1984).

The apparent variation in inbreeding rate among trees, and the distribution of maternal genotypes in our stand, could affect the portions of family relationships (i.e., selfs, half-sibs, and full-sibs) in its OP seed crops. If so, using such partly-inbred seed crops to obtain estimates of heritability and genetic gain will produce an overestimate, since a basic assumption in heritability determined from open-pollinated seed crops is that local relatedness and inbreeding do not exist to a significant degree (Namkoong, 1966; Squillace, 1974).

Implications for seed production If similar tree-totree variation in their inbreeding levels occurs in other western white pine stands, the use of seedproduction areas (natural stands managed for seed production during some part of their development) as seed sources may be questionable. If such a seed source is used (Hoff et al., 1976), several stands should be established per planting zone, and seed crops should be mixed prior to sowing to broaden the genetic base and reduce the likely impact of intra-stand inbreeding on the resultant plantations. Furthermore, seed orchards designed to minimise matings among members of one population should produce more-vigorous offspring than obtained from OP progeny. The presence of some amount of inbreeding in the McKay white pine population as a whole (coefficient 0.011 ) requires adjustment of the genetic parameters drawn from it. Furthermore, the apparent, near 2 -fold, variation among individual trees in their inbreeding rate necessitates a refined adjustment for each parent, if more-precise genetic information is to be obtained from OP progeny test plantations or from controlled crosses among trees with unknown genetic relatedness (Ghai, 1982; Cockerham and Weir, 1984). Otherwise, the ranking of white pine parent trees for measurable traits based on their open-pollinated progeny performance may simply reflect ephemeral differences in the proportions of inbreds, rather than genotypic superiority. 
Acknowledgements We gratefully acknowledge the careful reading, critical comments and helpful suggestions of $R$. S. Hunt, L. A. Mitchell, D. B. Neale, K. Ritland and E. E. White.

\section{REFERENCES}

ADAMS, W. T. AND JOLY, R. J. 1980. Genetics of allozyme variants in loblolly pine. $J$. Hered., 71, 33-40.

BINGHAM, R. T. 1973. Possibilities for improvement of western white pine by inbreeding. U.S.D.A. For. Serv., Res. Pap. INT-144, 18pp.

BINGHAM, R. T. 1983. Blister rust resistant western white pine for the Inland Empire: The story of the first 25 years of the research and development program. U.S.D.A., For. Serv., Gen. Tech. Rep. INT-146, 45pp.

BINGHAM, R. T. AND SQUILLACE, A. E. 1955. Self-compatibility and effects of self-fertility in western white pine. For. Sci., $1,121-129$.

BRADSHAW, A. D. 1972. Some of the evolutionary consequences of being a plant. Evol. Biol., 5, 25-47.

BROWN, A. H. D. 1979. Enzyme polymorphism in plant populations. Theor. Pop. Biol., 15, 1-42.

BROWN, A. H. D. AND ALLARD, R. W. 1970. Estimation of mating system in open pollinated maize population using isozyme polymorphisms. Genetics, 66, 133-145.

BROWN, A. H. D., BARRETT, S. C. H. AND MORAN, G. F. 1984. Mating system estimation in forest trees: models, methods and meanings. Gregorius, H.-R. (ed.) In Population genetics in Forestry, Springer-Verlag, Berlin, pp. 32-49.

CHELIAK, W. M., DANCIK, B. P., MORGAN, K., YEH, F. C. AND STROBECK, C. 1985. Temporal variation of the mating system in a natural population of jack pine. Genetics, 109, 569-584.

CLEGG, M. T. 1980. Measuring plant mating systems. Bioscience, $30,814-818$.

CLEGG, M. T. AND ALLARD, R. W. 1973. Viability versus fecundity selection in the slender wild oat, Avena barbata L. Science, 181, 667-668.

CLEGG, M. T., KAHLER, A. L. AND ALLARD, R. W. 1978. Estimation of life cycle components of selection in an experimental plant population. Genetics, 89, 765-792.

COCKERHAM, C. C. AND WEIR, B. S. 1984. Covariances of relatives stemming from a population undergoing mixed self and random mating. Biometrics, 40, 157-164.

CROW, J. F. AND FELSENSTEIN, J. 1968. The effect of assortative mating on the genetic composition of a population. Eugen. Q., 15, 85-97.

ECKERT, R. T., JOLY, R. J. AND NEALE, D. B. 1981. Genetics of isozyme variants and linkage relationships among allozyme loci in 35 eastern white pine clones. Can. J. For. Res., 11, 573-579.

EDWARDS, D. G. E. 1979. An improved air seed-sorter for laboratory use. Environment Canada, Can. For. Serv., Pac. For. Res. Cent., BC-X-188. $11 \mathrm{pp}$.

EL-KASSABY, Y. A. 1981. Genetic interpretation of malate dehydrogenase isozymes in some conifer species. J. Hered., 75, 451-452.

EL-KASSABY, Y. A., YEH, F. C. AND SZIKLAI, O. 1981. Estimation of the outcrossing rate of Douglas-fir (Pseudotsuga menziesii (Mirb.) Franco] using allozyme polymorphisms. Silvae Genet., 30, 182-184.

EL-KASSABY, Y. A., YEH, F. C. AND SZIKLAI, O. 1982. Inheritance of allozyme variants in coastal Douglas-fir (Pseudotsuga menziesii var. menziesii). Can. J. Genet. Cytol., 24, $325-335$
EL-KASSABY, Y. A., FASHLER, A. M. K. AND SZIKLAI, O. 1984. Reproductive phenology and its impact on genetically improved seed production in a Douglas-fir seed orchard. Silvae Genet., 33, 120-125.

ENNOS, R. A. 1981. Quantitative studies of the mating system in two sympatric species of Ipomoea (Convolvulaceae). Genetica, 57, 93-98.

ENNOS, R. A. AND CLEGG, M. T. 1982. Effect of population substructuring on estimates of outcrossing rate in plant populations. Heredity, 48, 283-292.

EPPERSON, B. K. AND ALLARD, R. W. 1984. Allozyme analysis of the mating system in lodgepole pine populations. $J$. Hered., 75, 212-214.

FYFE, J. L. AND BAILEY, N. T. J. 1951. Plant breeding studies in leguminous forage crops. I. Natural crossbreeding in winter beans. J. Agric. Sci., 41, 371-378.

GHAI, G. L. 1982. Covariances among relatives in populations under mixed self-fertilization and random mating. Bio metrics, 38, 87-92.

GURIES, R. P. AND LEDIG, F. T. 1978. Inheritance of some polymorphic isozymes in pitch pine (Pinus rigida Mill.). Heredity, 40, 27-32.

HAMRICK, J. L. 1982. Plant population genetics and evolution. Amer. J. Bot., 10, 1685-1693.

HOFF, R. J. 1982. Research on the genetics of pest resistance at the Intermountain Forest and Range Experiment Station. In Breeding Insect and Disease Resistant Forest Trees, U.S. For. Serv. Proc. of Servicewide Genetics Workshop. Eugene, OR, July, 1982, pp. 109-125.

HOFF, R. J., MCDONALD, G. I. AND BINGHAM, R. T. 1976. Mass selection for blister rust resistance: a method for natural regeneration of western white pine. U.S.D.A. For. Serv., Res. Note INT-202. $11 \mathrm{pp}$.

KING, J. N., DANCIK, B. P. AND DHIR, N. K. 1984. Genetic structure and mating system of white spruce (Picea glauca) in a seed production area. Can. J. For. Res., 14, 639-643.

LEVIN, D. A. AND KERSTER, H. W. 1968. Local gene dispersal in Phlox. Evolution, 22, 130-139.

LEVIN, D. A. AND KERSTER, H. W. 1971. Neighborhood structure in plants under diverse reproductive methods. Am. Nat., 105, 345-354.

LEVIN, D. A. AND KERSTER, H. W. 1974. Gene flow in seed plants. Evol. Biol., 7, 139-220.

LINHART, Y. B., MITTON, J. B., STURGEON, K. B. AND DAVIS, M. L. 1981. Genetic variation in space and time in a population of ponderosa pine. Heredity, 46, 407-426.

MEAGHER, M. D. AND HUNT, R. S. 1985. Proposed western white pine tree-improvement program for British Columbia. Can. For. Serv., Pac. For. Res. Cent., Victoria, B. C., Unpub. manuscript. 35pp. plus Appens.

MITTON, J. B. 1983. Conifers. Tanksley, S. D. and T. J. Orton (eds). In Isozymes in Plant Genetics and Plant Breeding, part B. Elsevier Science Publishers, Amsterdam, pp. 443472.

MITTON, J. B., LINHART, Y. B., DAVIS, M. L. AND STURGEON, K. B. 1981. Estimation of outcrossing in ponderosa pine, pinus ponderosa Laws., from patterns of segregation of protein polymorphisms and from frequencies of albino seedlings. Silvae Genet., 30, 117-121.

MORAN, G. F., BELL, J. C. AND MATHESON, A. C. 1980. The genetic structure and levels of inbreeding in a Pinus radiata D. Don seed orchard. Silvae Genet., 29, 190-193.

NAMKOONG, G. 1966. Inbreeding effects on estimation of genetic additive variance. For. Sci., 12, 8-13.

NEALE, D. B. 1985. Genetic implications of the Douglas-fir shelterwood regeneration system in southwest Oregon. For Sci., 31, 995-1005. 
NEI, M. AND SYAKUDO, K. 1958. The estimation of outcrossing in natural populations. Jap. J. Genet. 33, 46-51.

O'MALLEY, D. M., ALLENDORF, F. W. AND BLAKE, G. M. 1979. Inheritance of isozyme variation and heterozygosity in Pinus ponderosa. Biochem. Genet., 17, 233-250.

PARK, Y. S. AND D. P. FOWLER. 1982. Effects of inbreeding and genetic variances in a natural population of tamarack (Larix laricina (Du Roi) K. Koch) in eastern Canada. Silvae Genet., 31, 21-26.

RASMUSSEN, D. I. 1964. Blood group polymorphism and inbreeding in natural populations of deer mouse, Peromyscus maniculatus. Evolution, 18, 219-229.

REHFELDT, G. E., HOFF, R. J. AND STEINHOFF, R. J. 1984. Geographic patterns of genetic variation in Pinus monticola. Bot. Gaz., 145, 229-239.

RITLAND, K. AND EL-KASSABY, Y. A. 1985. The nature of inbreeding in a seed orchard of Douglas-fir as shown by an efficient multilocus model. Theor. Appl. Genet., 71, 375384.

RITLAND, K, AND JAIN, S. K. 1981. A model for the estimation of outcrossing rate and gene frequencies using $n$ independent loci. Heredity, 47, 35-52.

ROBERDS, J. H. AND CONKLE, M. T. 1984. Genetic structure in loblolly pine stands: allozyme variation in parents and progeny. For. Sci., 30, 319-329.

SAMMAN, S. 1982. The white pine blister rust program. Pacific Northwest Region, U.S. Forest Service. In Breeding Insect and Disease Resistant Forest Trees, U.S. For. Serv. Proc. of Servicewide Genetics Workshop, Eugene, OR., July, 1982, pp. 132-183.

SARVAS, R. 1962. Investigations on the flowering and seed crops of Pinus silvestris. Comm. Inst. For. Fenn., 53, 1-198.

SCHAAL, B. A. 1974. Isolation by distance in Liatris cylindracea. Nature, 252, 703.

SHAW, D. V. AND ALLARD, R. W. $1982 a$. Estimation of outcrossing rates in Douglas-fir using isozyme markers. Theor. Appl. Genet., 62, 113-120.
SHAW, D. V. AND ALLARD, R. W. 1982b. Isozyme heterozygosity in adult and open-pollinated embryo samples of Douglasfir. Silvae Fennica, 16, 115-121.

SHAw, D. V., KAHLER, A. L. AND ALlARD, R. W. 1981. A multilocus estimator of mating system parameters in plant populations. Proc. Nat. Acad. Sci. (USA), 78, 1298-1302.

SQUILLACE, A. E. 1974. Average genetic correlations among offspring from open-pollinated forest trees. Silvae Genet., $23,149-156$.

Steel, R. G. D. AND torrie, J. H. 1980. Principles and Pro cedures of Statistics: A Biometrical Approach, McGraw-Hill Book Company, Toronto.

STEINHOFF, R. J., JOYCE, D. G. AND FINS, L. 1983. Isozyme variation in Pinus monticola. Can. J. For. Res., 13, 11221131.

STERN, K. AND ROCHE, L. 1974. Genetics of Forest Ecosystems, Chapman and Hall Ltd., London.

TIGERSTEDT, P. M. A. 1973. Studies on isozyme variation in marginal and central populations of Picea abies. Hereditas, $75,47-60$.

TOWNSEND, A. M., HANOVER, J. W. AND BARNES, B. V. 1972. Altitudinal variation in photosynthesis, growth and monoterpene composition of western white pine (Pinus monticola Dougl.) seedlings. Silvae Genet, 21, 133-139.

WAHLUND, S. 1928. Zammensetzung von Populationen und Korrelationsershienungen vom Standpunkt der Vererbungslehre aus betrachtet. Hereditas, 11, 65-106.

WAllis, G.W. 1976. Phellinus (Poira) weirii root rot. Detection and management proposals in Douglas-fir stands. Environment Canada, Can. For. Serv., Pac. For. Res. Cent., Victoria, B.C., Forestry Tech. Rep. 12, 16pp.

WRIGHT, S. 1922. Coefficients of inbreeding and relationship. Am. Nat., 56, 330-338. 